\title{
Gonococcal Infection of Genitourinary Tract
}

National Cancer Institute

\section{Source}

National Cancer Institute. Gonococcal Infection of Genitourinary Tract. NCI Thesaurus.

Code C35621.

A genitourinary infection that is caused by Neisseria gonorrhoeae. 